\title{
Forecasting the transport network development based on statistical analysis in the MIX-PROSTOR system ${ }^{1}$
}

\author{
M.A. Bulyonkov, N.N. Filatkina
}

\begin{abstract}
We are considering the problem of the analysis of transport network development in the MIX-PROSTOR system. The "what-if" analysis allows for setting some variations of the network parameters and calculating their consequences. In a sense, we are trying to solve the inverse problem: what ranges of network parameter modification leads to a required resulting network usage? We exploit a statistical approach to the problem, calculating a large number of solutions corresponding to varying parameters, and then analyzing the set of solutions for correlations with respect to the property being investigated.
\end{abstract}

Keywords: research automation system, "what-if" forecasting, statistical analysis, development of the transport system.

\section{Introduction}

In the paper, we are considering an approach to transport problem solution, which, generally speaking, may have a large spectrum of various aspects depending on the level of consideration and objectives. Thus, a lot of research is going on in the optimal planning of urban transport traffic and city development. Here, the main accents are put on the dynamics of the load of roads, rationale for the construction of new roads and junctions, imposing restrictions on certain type of vehicles, and so on. [1,2]. At the corporate level, the transport task assumes the transport network to be unchanged and more attention is paid to warehousing, timely delivery, etc.

In this paper, we approach the problem at the state, inter-corporate level, and the goal is to determine the conditions (the development of the transport network and tariff policy) that would ensure the overall optimal transportation of goods from producers to consumers.

We are considering optimality only in terms of minimizing the cost of transporting products. Naturally, optimality may involve other considerations, not necessarily economic (see, for example, [3]). In addition, the model we use is limited to static analysis, assuming, for example, non-varying volumes of production and consumption. Forecasting and variation of such parameters is

1 Supported by RFH Project \#16-02-00221a "Modeling the process of development of the northern territories and water areas of Russia: the game approach based on geoinformation technologies". 
performed by an expert. The dynamics of the transport network development was considered in [4], where for each node its potential is considered, understood as an excess or shortage of the given commodity.

In previous works $[5,6]$, a system for economic research automation, MIXPROSTOR, was described, which essentially provides an environment for a solver of the transport task. At that time we mostly focused on the problem of the huge size and complexity of both solver's input data and results. The MIXPROSTOR system, on the one hand, provides a user-friendly interface for setting all parameters of the transport network, such as topology, length of roads, tariffs of transportation and handling, volumes of production and consumption of specific products in different nodes, etc., and on the other hand, allows displaying the modeling results "right on the map", with the possibility to highlight certain aspects, such as traffic load, transportation of a separate product, etc. A typical snapshot of how the MIX-PROSTOR system works is shown in Figure 1.

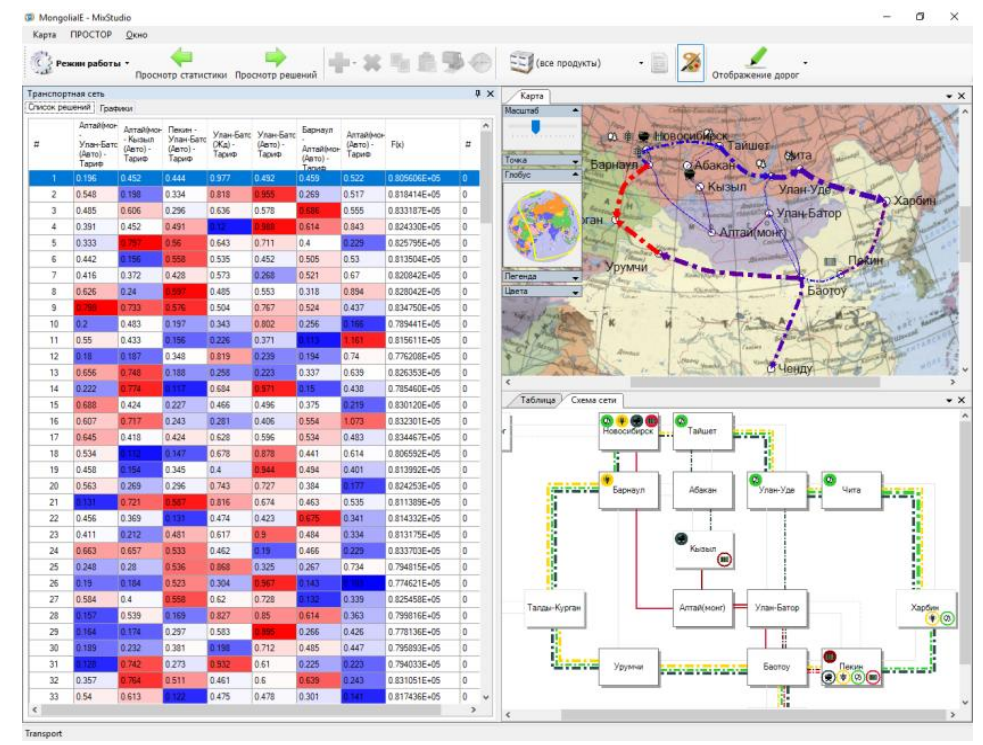

Figure 1. The MIX-PROSTOR system

As the time spent on an experiment became much shorter thanks to the MIXPROSTOR, which automated most of routine and purely technical work, it made it possible to conduct large series of experiments and hence to systematize them: store and sort by various parameters, input and output data, compare simulation results, and so on. Now, we are facing a new level of problems: reaching an understanding of what an expert was trying to find using the tools provided and how we can help it [7]. 


\section{Formalization}

To solve the problems of forecasting the transport network development, we use the economic model [8], operating with the following sets: $\mathrm{P}$ is the set of all product types, $\mathrm{T}$ is the set of all transport types, and $\mathrm{R}$ is the set of all hubs. Each transport line is defined by a pair of hubs and the mode of transport: ( $t, r, r$ '). The following restrictions are imposed on network parameters:

1. Constraints on loading and unloading. Let $A_{r}^{p}$ denote the volume of the product $p$ produced at the hub $r, X_{t r}^{p}$, the volume of the product $p$ loaded on the transport $t$ at the hub $r, B_{r}^{p}$, the volume of the product $p$ consumed at the hub $r$, and $Y_{t r}^{p}$, the volume of the product $p$ unloaded from the transport $t$ at the hub $r$, then $\sum_{t} X_{t r}^{p} \leq A_{r}^{p}, \quad \sum_{t} Y_{t r}^{p} \geq B_{r}^{p}$

2. Constraint on processing at a hub. If $Z_{t r}^{p}$ is the volume of the product $p$ that is transitory on the transport $t$ at the hub $r, V_{t t^{\prime} r}^{p}$ is the volume of the product $\mathrm{p}$ re-loaded from the transport $t$ to the transport $t^{\prime}$ at the hub $r$, $W_{t^{\prime} r}^{p}$ is the volume of the product $p$ arriving to $r$ by the line $\left(t, r^{\prime}, r\right)$, and $W_{t r r^{\prime}}^{p}$ is the volume of the product $p$ departing from $r$ by the line $\left(t, r, r^{\prime}\right)$, then

$\sum_{r^{\prime}} W_{t r^{\prime} r}^{p}=Y_{t r}^{p}+\sum_{t^{\prime}} V_{t t^{\prime} r}^{p}+Z_{t r}^{p}, \quad X_{t r}^{p}+\sum_{t^{\prime}} V_{t t^{\prime} r}^{p}+Z_{t r}^{p}=\sum_{r^{\prime}} W_{t r r^{\prime}}^{p}$.

3. Constraint on the carrying capacity $P_{t r r^{\prime}}$ of the line $\left(t, r, r^{\prime}\right)$ taking into account transportation in both directions, i.e. $P_{t r r^{\prime}}=P_{t r^{\prime} r}$ :

$$
\sum_{p}\left(W_{t r r^{\prime}}^{p}+W_{t r^{\prime} r}^{p}\right) \leq P_{t r r^{\prime}}
$$

The objective function of the model is the overall costs of products processing at transport hubs and and their transportation:

$\sum_{t, r, p} \stackrel{\mathbf{I}}{c}_{t}^{p} X_{t r}^{p}+\sum_{t, r, p} \stackrel{\mathrm{s}}{c_{t}} p_{Y_{t r}^{p}}+\sum_{t, r, p} \bar{c}_{t}^{p} Z_{t r}^{p}+\sum_{t, t^{\prime}, r, p} c_{t t^{\prime}, r}^{p} V_{t t^{\prime} r}^{p}+\sum_{t, r, r^{\prime}, p} \varphi_{t r r^{\prime}}^{p} l_{t r r^{p}}^{p} W_{t r r^{\prime}}^{p} \rightarrow \min$,

where the coefficients $\stackrel{\mathrm{r}}{c}_{t}^{p}, \stackrel{\mathrm{s}_{t}^{p}}{\mathrm{~s}_{t}}, \bar{c}_{t}^{p}, \quad c_{t^{\prime} \text { r }}^{p}$ are specific factors with respect to a unit of cargo, $l_{t r}^{p}$ is the length of the line $\left(t, r, r^{\prime}\right)$, and $\varphi_{t r}^{p}$ is the cost of transportation along the line per unit of cargo and unit of length.

Thus, we have a simplified formulization, where the coefficients for the variables $X_{t r}^{p}, Y_{t r}^{p}, Z_{t r}^{p}, V_{t t^{\prime} r}^{p}, W_{t r r^{\prime}}^{p}$ are assumed constant. This problem can be solved with the help of an appropriate linear programming package (see e.g. [9]). We have 
adopted this simplification of non-varying tariffs, since otherwise we would have to deal with a much more complicated/difficult non-linear case.

Summarizing the above, the solution determines which lines (and in which direction) should be used to transport each product, taking into consideration the given places and volumes of production and consumption, tariffs and carrying capacity of the lines.

Note several obvious consequences of this formulation of the problem. First, as mentioned in Introduction, the solution is optimal only by and large; there may be a better solution to bring a separate single product from a specified producer to a customer. The solution optimizes the costs associated with the transport of goods, and not the revenue of carriers.

The task of the researcher (in this context we will identify him/her with the decision-maker) is to find out how the input parameters affect the output in order to answer such sustantive questions as

1. How much should the tariff for a given line be reduced so that this line starts to be used? Or maybe the usage of the line depends on some other things?

2. Does it make sense to increase the capacity of a given line?

3. Does it make sense to organize a transport logistics center at the given hub of the network in order to reduce the cargo processing cost?

Each such question depends on the objectives and authority of the decision maker, i.e. his or her ability to influence a limited set of parameters. For example, imagine a situation where we can change freight tariffs for the Trans-Siberian railway or build a logistics center in Kyzyl, but we cannot directly influence the tariff policy of the PRC authorities.

Evidently, the (naïve) approach considering tariffs and capacities as additional variables in the above system of inequalities is not productive. It is clear that the minimization the total costs will be achieved if we set minimum tariffs and maximum capacities. Moreover, this approach would make the problem described above non-linear.

In fact, the problem is essentially two-phase:

1. For each set of values of variable parameters, the solver produces a single point in the multi-dimensional space of parameters and resulting variables.

Each question implies a selection of a specific sub-area in the obtained set, which is a subject of further investigation. For example, the request to use a particular line $\left(t, r, r^{\prime}\right)$ for the product $p$ with certain restrictions on transportation tariffs can be expressed as additional inequalities:

$W_{t r r^{\prime}}^{p}+W_{t r^{\prime} r}^{p}>0 \& \varphi_{t r r^{\prime}}^{p} \in\left[k_{1}, k_{2}\right]$. 


\section{Our approach}

Of course, an ideal solution to the problem would be an analytical description of the multi-dimensional area specifying the answer to the expert's question. Unfortunately, it is too hard or sometimes impossible to obtain, which made us look for approximate methods of analysis.

The MIX-PROSTOR system [10] allows the expert to set variation ranges for a selected subset of input parameters and then generate a set of test cases complying with the restrictions imposed. The system provides two methods to generate test sets:

1. The uniform method, which incrementally and independently varies each parameter for a parameter with a specified step. The set of test cases is therefore a multi-dimensional rectangle with a uniform grid.

2. The probabilistic method, which randomly selects a set of points in the indicated domain rectangle. The advantage of this approach is a greater number of points for each dimension.

Next, the optimization problem is solved for each test set giving the values of the resulting variables. Based on the information collected, we try to answer the questions asked by various experts, some of which are discussed below.

\section{Line expediency conditions}

Question from an expert: For what ranges of parameter values will this line be used in at least in $75 \%$ of the solutions?

The formulation of the question allows us to classify each decision depending on the volume of transportation for this particular line. In the simplest case, we split the entire set of solutions into two classes: the ones in which the line is used (a bright dot) and the ones in which it is not used (a pale dot).

We are trying to give an idea of the resulting set of points by considering its projections.

The one-dimensional projection shows how the value of a resulting variable depends on a single selected parameter. Examples of such projections are shown in Figure 2, where the resulting variable is the volume of transportation on the line Altai-Kyzyl. One can notice that most of the values are equal to either the maximum or zero, which means that the line is either used to its full capacity or not used at all. The first two graphs have ranges of parameter value, for which the observed variable values are mostly the same. On the contrary, on the third graph the observed variable looks like random, which means that in all probability there is no dependence between the value of the parameter and the value of the variable. In this way, we help to answer the above question of an expert by automatically selecting the range of a maximum width, where the number of nonzero values is over $75 \%$. A similar range is calculated for zero values with the 
threshold of $95 \%$. In case any of these ranges is detected, we also calculate the coefficient of positive and/or negative correlation.

The two-dimensional projection allows us to display the case when the value of a variable depends on two parameters. A typical example is the sequence of two lines $-(t, r 1, r 2)$ and $(t, r 2, r 3)$, the total transportation cost for which is described by the formula

$$
\varphi_{t t_{1} z_{2}}^{p} l_{t r_{1} r_{2}}^{p} W_{t_{1_{1}} r_{2}}^{p}+Z_{t_{t_{2}}}^{p}+\varphi_{t_{t_{2}} r_{3}}^{p} l_{t_{2} r_{3}}^{p} W_{t t_{2} r_{3}}^{p} .
$$

If there are no other lines suitable for this product from the intermediate hub $r 2$ and if the product is neither produced nor consumed at $r 2$, then in any solution both lines are either simultaneously used or not used. Furthermore, the usage condition is essentially a constant constraint on the total value described above, from which it is impossible to obtain ranges for each of the parameters $W_{t_{1} r_{2}}^{p}$ and $W_{t_{2} r_{3}}^{p}$ separately. A similar situation can be observed for "alternative" lines.

The problem is complex because we are rarely able to establish the simple cases of line connection described in the transport network, and we can distinguish between "sequentional" and "alternative" lines only based on the actual usage in a specific solution.

We may consider the problem as the construction of a classifier of the multidimensional point cloud [11] that separates bright and pale points. Given the nature of the transport problem, we used a linear classifier. For each pair of parameters, we try to divide the set of points graphically, by a straight line. An example of a two-dimensional projection is shown in Figure 3.

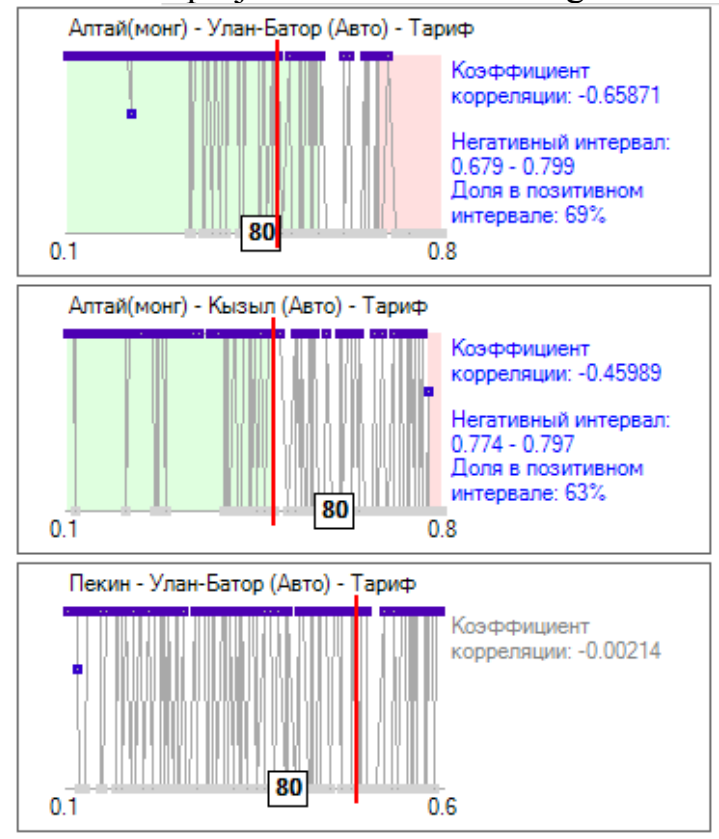

Figure 2. One-dimensional projections 


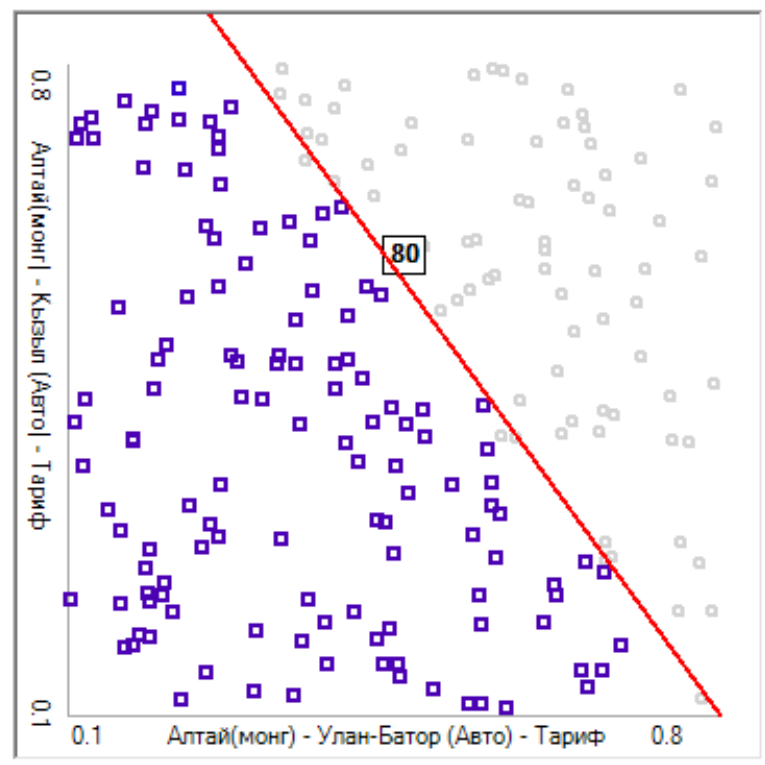

Figure 3. Two-dimensional projections

Thus, we essentially project the point cloud on two dimensions. Clearly, if the value of a resulting variable correlates (positively or negatively) to more than two parameters, instead of a clear boundary of the region we will have a gradient change of the density of points in a two-dimensional projection.

\section{Correlation}

Question from an expert: What affects the volume of traffic on this line?

The answer to this question is obvious only for straightforward cases, for example, the volume of transportation along the line depends on the tariff for this line. Yet, even this case may show no dependence if transportation on the line is "blocked" by other parameters.

The accumulated statistics allow us to determine such dependencies on the basis of calculating the Pearson correlation coefficient [12], assuming that parameter values and transportation volumes along the selected line are two sets of random values. Positive and negative values of the coefficient indicate direct and inverse dependencies, respectively.

The results can be compactly represented in the form of a matrix, where rows correspond to lines, and columns correspond to parameters. The cells of the matrix are colored red for positive correlation, blue for negative, and without colour when no correlation is detected. 
The matrix obtained can turn out to be rather "patchy". In order to improve the display, the rows and columns of the matrix can be rearranged so as to achieve the following condition: two lines should be displayed close to each other if they depend on the same parameters similarly; and the other way round, two parameters should be displayed close to each other if they the same lines similarly affect. To solve this problem, we use a heuristic algorithm that iteratively applies the following action:

1. For each line calculate the barycenter of all parameters affecting the line, taking the coefficient of correlation as mass, and position of the parameter as its coordinate.

2. Swap the position of two lines if their order does not correspond to the order barycenters.

3. Apply similar permutation for the columns of the matrix.

The results of this method are shown in Figure 4.

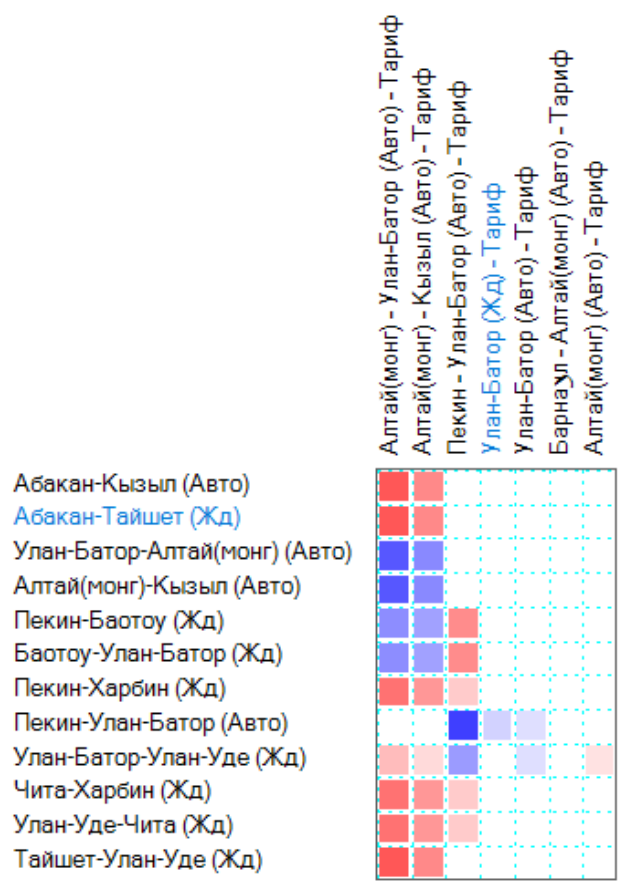

(a)

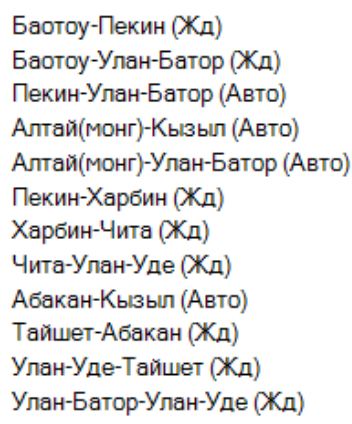

Баотоу-Пекин (Жд)

Баотоу-Улан-Батор (Жд)

Пекин-Улан-Батор (Авто)

Алтай(монг)-Кызыл (Авто)

Алтай(монг)-Улан-Батор (Авто)

Пекин-Харбин (Жд)

Харбин-Чита (Жд)

Чита-Улан-Уде (Жд)

Абакан-Кызыл (Авто)

Тайшет-Абакан (Жд)

Улан-Уде-Тайшет (Жд)

Улан-Батор-Улан-Уде (Жд)

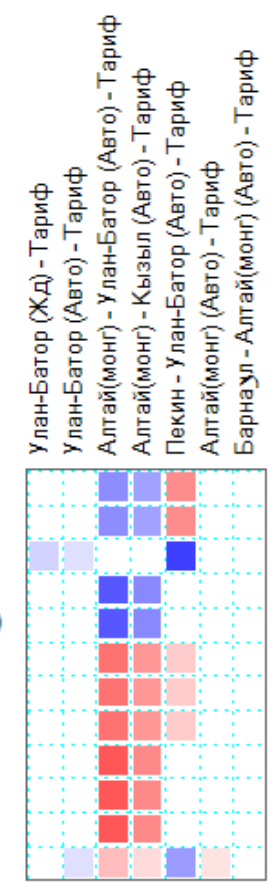

(b)

Figure 4. Correlation matrix: (a) prior to reordering, (b) after reordering 


\section{Transportation corridors}

A similar matrix can be constructed for pairs of the lines of a transport network, by calculating the correlation of transportation volumes for each pair. An example of such a correlation matrix is shown in Figure 5.

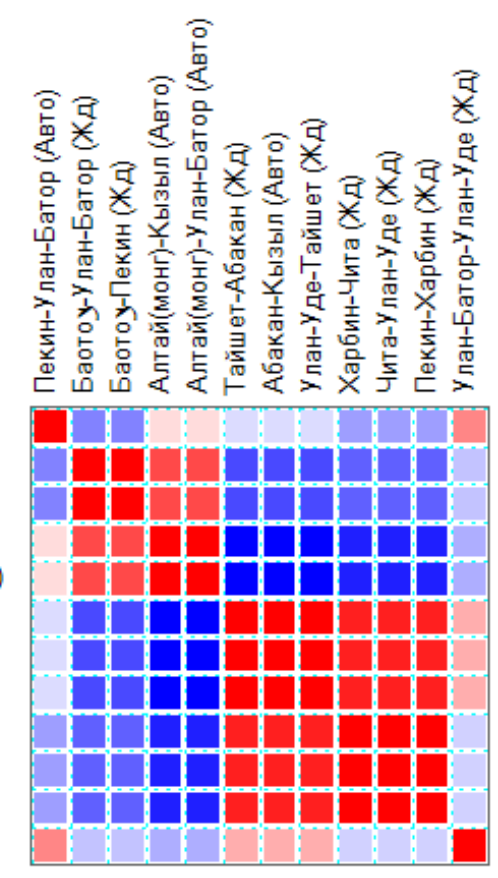

Пекин-Улан-Батор (Авто)

Баотоу-Улан-Батор (Жд)

Баотоу-Пекин (Жд)

Алтай(монг)-Кызыл (Авто)

Алтай(монг)-Улан-Батор (Авто)

Тайшет-Абакан (Жд)

Абакан-Кызыл (Авто)

Улан-Уде-Тайшет (Жд)

Харбин-Чита (Жд)

Чита-Улан-Уде (Жд)

Пекин-Харбин (Жд)

Улан-Батор-Улан-Уде (Жд)

Figure 5. Correlation matrix of transportation volumes

The method of rearranging rows and columns described above can be applied to this matrix as well, which clearly reveals groups of interdependent lines. In this example, there are two competing transportation corridors for the selected product: Kyzyl-Ulan-Bator-Baotou-Beijing and Kyzyl-Abakan-Taishet-UlanUde-Chita-Harbin-Beijing. Such information prompts the expert that the tariffs within the corridors should change synchronously.

\section{Flow analysis}

Question from an expert: Is it possible to increase the use of a line by reducing its transportation tariffs?

This issue usually arises after a series of experiments during which the transportation tariffs for this line were constantly decreasing, but the line remained unused. Clearly, the reason for this can be the topology of the transport 
network: there is no way from the producer to the consumer at all. It is also possible that the line is not used because of a too high tariff on the other line from the general corridor, or a very low tariff on a line from the competing corridor.

The key information for the question is the minimal transportation cost of a product unit from a producer $r_{A}$ to a consumer $r_{B}$ along the same route, which includes the line of interest $e_{0}=\left(t, r 0, r^{\prime} 0\right)$. We solve the problem using the technique of global flow analysis [13].

We annotate the transport network by marking each line $e$ with a pair of values: $w_{e}$ is the current minimum cost of transportation from the hub $r_{A}$ to the line $e$ and $w_{e}{ }^{\prime}$ is the current minimum cost of transportation along the routes passing through the line $e_{0}$. The initial markup for the product $\mathrm{p}$ is defined as follows:

$$
\begin{aligned}
w_{e} & =\left(\begin{array}{l}
\mathrm{r}_{t}^{p}+\varphi_{t r_{A} r^{r}}^{p} l_{t r_{A} r^{r}}^{p}, \text { for lines }\left(t, r A, r^{\prime}\right) \\
+\infty, \text { otherwise }
\end{array}\right) \\
w_{e}^{\prime} & =\left(\begin{array}{l}
w_{e}^{\prime}, \text { for line } e=e_{0} \\
+\infty, \text { otherwise }
\end{array}\right) .
\end{aligned}
$$

The marking propagation from a line $e^{\prime}=\left(t^{\prime}, r^{\prime}, r_{1}\right)$ to $e=\left(t, r_{1}, r_{2}\right)$ is defined as the function $f_{e^{\prime},}(x)$ :

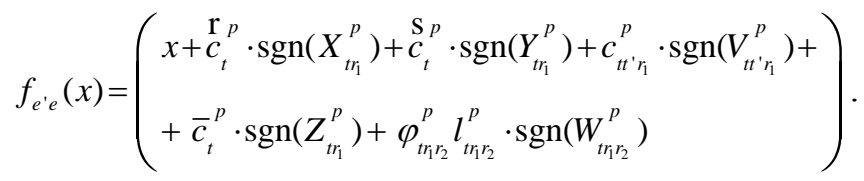

The use of $\operatorname{sgn}$ here means that we are considering the transportation of a unit volume of a product.

Taking the component-wise minimum over the pairs of values as greatest upper bound I, we obtain a semi-lattice, which is evidently bounded from below by zeros. The single step of a fixed point flow analysis iteration is defined as follows:

$$
\begin{aligned}
& w_{e}=w_{e} \mathrm{I} f_{e^{\prime} e}\left(w_{e^{\prime}}\right) \\
& w_{e}^{\prime}=\left(\begin{array}{l}
w_{e}^{\prime} \mathrm{I} f_{e^{\prime} e}\left(w_{e^{\prime}}^{\prime}\right) \mathrm{I} f_{e^{\prime} e}\left(w_{e^{\prime}}\right), \text { for line } e=e_{0} \\
w_{e}^{\prime} \mathrm{I} f_{e^{\prime} e}\left(w_{e^{\prime}}^{\prime}\right), \text { otherwise }
\end{array}\right) .
\end{aligned}
$$

It is easy to enhance the semi-lattice without violating the convergence properties so that each cost value is annotated with the route that realizes the cost.

A similar problem can also be formulated with respect to a particular solution: the lines that are not used for the product are discarded from the network. Thus, for each line and fixed producer and consumer hubs, we get two values:

1. the minimum cost through the line not taking into account other products, and

2. the maximum detected cost for the solution. 
Both extremes are taken over all routes from the producer to customer going through the given line. Examples of such comparisons are shown in Figure 6, where the table columns display paths associated with the extremes; the line of interest is highlighted.

\begin{tabular}{|c|c|c|c|}
\hline \multicolumn{4}{|c|}{ Барнаул - Пекин } \\
\hline $\begin{array}{l}\text { Максимальный } \\
\text { решении }\end{array}$ & 875 & $\begin{array}{l}\text { Минимальный } \\
\text { через выбранное } \\
\text { плечо }\end{array}$ & 1263.977 \\
\hline $\begin{array}{l}\text { Барнаул } \\
\text { (погрузка) }\end{array}$ & \multicolumn{2}{|r|}{ 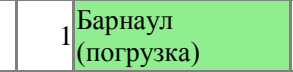 } & 10 \\
\hline Жд & 270 & Авто & 400 \\
\hline $\begin{array}{l}\text { Талды-Курган } \\
\text { (транзит) }\end{array}$ & \multicolumn{2}{|c|}{$1 \quad \begin{array}{l}\text { Абакан } \\
\text { (перегрузка) }\end{array}$} & 10 \\
\hline Жд & 240 & Жд & 160 \\
\hline Урумчи (транзит) & \multicolumn{2}{|c|}{1 Тайшет (транзит) } & 1 \\
\hline Жд & 200 & Жд & 300 \\
\hline Баотоу (транзит) & & $1 \mid \begin{array}{l}\text { Улан-Уде } \\
\text { (транзит) }\end{array}$ & 1 \\
\hline \multirow[t]{3}{*}{ Жд } & 160 & Жд & 120 \\
\hline & & $\begin{array}{l}\text { Улан-Батор } \\
\text { (транзит) }\end{array}$ & 0.977 \\
\hline & & Жд & 260 \\
\hline Пекин (разгрузка) & & 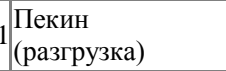 & 1 \\
\hline
\end{tabular}

\begin{tabular}{|c|c|c|c|}
\hline \multicolumn{4}{|c|}{ Барнаул - Ченду } \\
\hline $\begin{array}{l}\text { Максимальный } \\
\text { решении }\end{array}$ & 855 & \begin{tabular}{|ll} 
Минимальный \\
через \\
плечо
\end{tabular} & 1304.977 \\
\hline $\begin{array}{l}\text { Барнаул } \\
\text { (погрузка) }\end{array}$ & & Барнаул (погрузка) & 10 \\
\hline Жд & 270 & Авто & 400 \\
\hline $\begin{array}{l}\text { Талды-Курган } \\
\text { (транзит) }\end{array}$ & & $\begin{array}{l}\text { Абакан } \\
\text { (перегрузка) }\end{array}$ & 10 \\
\hline Жд & 240 & Жд & 160 \\
\hline $\begin{array}{l}\text { Урумчи } \\
\text { (транзит) }\end{array}$ & & Тайшет (транзит) & 1 \\
\hline Жд & 200 & Жд & 300 \\
\hline Баотоу (транзит) & & $\begin{array}{l}\text { Улан-Уде } \\
\text { (транзит) }\end{array}$ & 1 \\
\hline \multirow[t]{5}{*}{ Жд } & 40 & Жд & 120 \\
\hline & & $\begin{array}{l}\text { Улан-Батор } \\
\text { (транзит) }\end{array}$ & 0.977 \\
\hline & & Жд & 160 \\
\hline & & Баотоу (транзит) & 1 \\
\hline & & Жд & 140 \\
\hline $\begin{array}{l}\text { Ченду } \\
\text { (разгрузка) }\end{array}$ & 1 & Ченду (разгрузка) & 1 \\
\hline
\end{tabular}

Figure 6. Comparison of optimal path costs

The flow analysis allows us to find a gap the between the minimum cost of a single product transportation from a specified producer to a specified consumer and the maximum cost of this value estimated for some of the solutions with the requirement to use the line of interest. We can then find the minimum of this gap over all products, producers, and consumers. The two routes found in this way give the expert information about the critical parameters: the tariffs on the first route should be decreased and the ones on the second route should be increased so that the line of interest is used. The transportation from Barnaul to Beijing is an example (Figure 6). Suppose that we can influence only the tariff on the line Barnaul-Abakan. Then the line will be used only if the tariff is reduced to almost zero. 


\section{Summary information}

The results described above, obtained using the statistical analysis of the solution set or through the massive application of flow analysis, can be summarized in the table shown in Figure 7 giving the following data for each line of the transport network:

1. Use (in percent) showing how often this line was involved in solutions;

2. Gaps in use:I If the line is not used at all, what is the minimum cost of its involvement in the transport network and what are the values of the critical parameters?

3. Maximum load is the maximum value of the ratio of the total volume of products transported along the line to its capacity, over the whole solution set;

4. Maximum volume is the maximum value of the volume of the product transported;

5. Average volume and average load are the average values of the corresponding parameters over the whole set of solutions.

\begin{tabular}{|c|c|c|c|c|c|c|c|}
\hline Плечо & $\begin{array}{l}\text { Вид } \\
\text { транспо }\end{array}$ & $\begin{array}{l}\% \\
\text { испольs }\end{array}$ & $\begin{array}{l}\text { Перспек } \\
\text { вариант }\end{array}$ & $\begin{array}{l}\text { Макс. } \\
\text { загруже। }\end{array}$ & $\begin{array}{l}\text { Cp. } \\
\text { загруженнос }\end{array}$ & $\begin{array}{l}\text { Макс. } \\
\text { объём }\end{array}$ & $\begin{array}{l}\text { Cp. } \\
\text { объём }\end{array}$ \\
\hline Алтай(монг)-Кызыл & Авто & 61.50 & & 30.00 & 18.40 & 3.00 & 1.84 \\
\hline Алтай(монг)-Улан-Б... & Авто & 61.50 & & 30.00 & 18.40 & 3.00 & 1.84 \\
\hline Баотоу-Улан-Батор & Жд & 44.50 & & 3.00 & 1.34 & 3.00 & 1.34 \\
\hline Баотоу-Пекин & Жд & 44.50 & & 2.00 & 0.89 & 3.00 & 1.34 \\
\hline Тайшет-Улан-Уде & Жд & 39.00 & & 1.50 & 0.58 & 3.00 & 1.16 \\
\hline Абакан-Тайшет & Жд & 39.00 & & 5.00 & 1.93 & 3.00 & 1.16 \\
\hline Абакан-Кызыл & Авто & 39.00 & & 30.00 & 11.60 & 3.00 & 1.16 \\
\hline Пекин-Харбин & Жд & 32.50 & & 5.00 & 1.63 & 3.00 & 0.98 \\
\hline Улан-Уде-Чита & Жд & 32.50 & & 2.00 & 0.65 & 3.00 & 0.98 \\
\hline Чита-Харбин & Жд & 32.50 & & 2.00 & 0.65 & 3.00 & 0.98 \\
\hline Пекин-Улан-Батор & Авто & 23.00 & & 30.00 & 6.90 & 3.00 & 0.69 \\
\hline Улан-Батор-Улан-Уде & Жд & 6.50 & & 7.50 & 0.46 & 3.00 & 0.19 \\
\hline Абакан-Барнаул & $W_{\mathrm{a}}$ & 0.00 & 14 & 0.00 & 0.00 & 0.00 & 0.00 \\
\hline Барнаул-Алтай(монг) & Авто & 0.00 & 14 & 0.00 & 0.00 & 0.00 & 0.00 \\
\hline Барнаул-Новосибирск & Авто & 0.00 & 14 & 0.00 & 0.00 & 0.00 & 0.00 \\
\hline Екатеринбург-Ново... & Жд & 0.00 & 14 & 0.00 & 0.00 & 0.00 & 0.00 \\
\hline Урумчи-Талды-Курган & Жд $_{1}$ & 0.00 & 159 & 0.00 & 0.00 & 0.00 & 0.00 \\
\hline Екатеринбург-Ново.... & Авто & 0.00 & 14 & 0.00 & 0.00 & 0.00 & 0.00 \\
\hline Чита-Харбин & Авто & 0.00 & 3 & 0.00 & 0.00 & 0.00 & 0.00 \\
\hline Улан-Уде-Чита & Авто & 0.00 & 3 & 0.00 & 0.00 & 0.00 & 0.00 \\
\hline Пекин-Харбин & Авто & 0.00 & 3 & 0.00 & 0.00 & 0.00 & 0.00 \\
\hline Абакан-Кызыл & Жд & 0.00 & 148 & 0.00 & 0.00 & 0.00 & 0.00 \\
\hline Улан-Батор-Улан-Уде & Авто & 0.00 & 156 & 0.00 & 0.00 & 0.00 & 0.00 \\
\hline Екатеринбург-Талд... & Жд & 0.00 & 159 & 0.00 & 0.00 & 0.00 & 0.00 \\
\hline Новосибирск-Тайшет & Авто & 0.00 & 159 & 0.00 & 0.00 & 0.00 & 0.00 \\
\hline Екатеринбург-Талд... & Авто & 0.00 & 159 & 0.00 & 0.00 & 0.00 & 0.00 \\
\hline I- & W- & $n \mathrm{nn}$ & $10 n$ & $n \mathrm{nn}$ I & $n \mathrm{nn}$ & $n \mathrm{nn}$ & $n n n$ \\
\hline
\end{tabular}

Figure 7. Summary statistics table 


\section{Conclusion}

We have considered some possibilities of the statistical analysis of a set of solutions of the transport problem. The practical use of the MIX-PROSTOR system has shown that this approach significantly facilitates the expert's forecast analysis of the transport network development and leverages the reasoning of the decision-maker.

We are considering the following potential improvements and extensions of the methods addressed in the paper. First, we can examine the correlation of transportation volumes not only between individual lines, but also between different corridors, which were identified by other methods. Secondly, the flow analysis for finding the minimum transportation costs deals with a single product and, therefore, ignores the fact that some lines may not be available because they are engaged in the transportation of other products.

The variety of the aspects of this problem requires specialized visualization methods. Three-dimensional graphics seems to be an obvious generalization. Its prospects, however, are questionable due to the large dimensionality of the task and complexity of an adequate visualization of the "point cloud".

Furthermore, we plan to enhance integration with other components of the MIX system, which would allow taking into account not only the parameters of the transport network, but also the tendencies of the economic development of the regions.

\section{References}

[1] Shvetsov V.I. Mathematical modeling of transport flows // Avtomat. and Telemeh. - 2003. - No. 11. - P. 3-46; Autom. Remote Control. - 2003. - Vol. 64, No. 11. - P. 1651-1689 (In Russian).

[2] Shamray N.B. Search for flow equilibrium by projective methods using decomposition and generation of routes // Avtomat. and Telemeh. - 2012. - No. 3. - P. 150-165; Autom. Remote Control. - 2012. - Vol. 73, No. 3. - P. 547-560 (In Russian).

[3] Prokhorov A.V., Ilyin I.V. Information-analytical systems and estimation of economic efficiency of transport planning projects // Scientific and technical statements of SPbSPU 6'2010. - 2010. - P. 291 (In Russian).

[4] Stepantsov M.E. On the possible modification of the discrete mathematical model of the dynamic development of the transport network // Computer Studies and Modeling. - 2013. - Vol. 5, No. 3. - P. 395-401 (In Russian). 
[5] Vorobyova V.V., Malov V.Yu., Marusin V.V., Radchenko V.V. Forecasting the development of a basic transport network: a tool for variant calculations // Siberia and the Far East in the long-term strategy for the development of the integrated transport infrastructure of Eurasia / Ed. S.N. Vasilyeva [and others]; IrGUPS [and others]. - Irkutsk-Moscow-Novosibirsk, 2011. - Ch. 4.15. - P. 516-522 (In Russian).

[6] Bulyonkov M.A., Karpan V.V., Malov V.Yu., Marusin V.V., Radchenko V.V. Conceptual issues of the construction of the Model-Information-Cartographic System (MICS) // Modeling of production and regional systems based on GIS and information technologies: coll. sci. tr. / Ed. J.S. Blama, V.V. Radchenko. Novosibirsk: IEEPP SB RAS, 2011. - P. 5-28 (In Russian).

[7] Bulyonkov M.A., Filatkina N.N. The system for automation of research in macroeconomic modeling // Bulletin NCC. Series: Computer Science. Novosibirsk, 2015. - IIS Special Iss. 38. - P. 51-66.

[8] Vorobyova V.V., Malov V.Yu., Radchenko V.V., Potter M.V., Serebryannikov I.E. Model of forecasting the development of a basic transport network // Modeling of industrial and regional systems based on GIS and information technologies: coll. sci. tr. / Ed. J.S. Blama, V.V. Radchenko. - Novosibirsk: IEEPP SB RAS, 2011. - P. 68-96 (In Russian).

[9] Zabinyako G.I. The package of programs for integer linear programming // Discrete. Analysis and Issled. Oper. Ser. 2. - 1999. - Vol. 6, No. 2. - P. 32-41 (In Russian).

[10] Bulyonkov M.A., Filatkina N.N. Situational analysis in the transport forecasting system MICS-PROSTOR // Information Technologies. - 2013. - No. 8. - P. 43-52.

[11] Vyugin V. Mathematical foundations of machine learning and forecasting. MCIS, 2014.

[12] Suslov V.I., Ibragimov N.M., Talysheva L.P., Tsyplakov A.A. Econometrics. Novosibirsk: Siberian Branch of the Russian Academy of Sciences, 2005.

[13] Kotov V.E., Sabelfeld V.K. Theory of Program Schemes. - M.: Nauka, 1991. 